\title{
Economic security potential management mechanism of enterprises in the system of strategic decisions
}

\author{
Olena Arefieva ${ }^{1}$, Yuri Kopcha ${ }^{2}$, Volodymyr Arefiev ${ }^{3}$, Iryna Miahkykh ${ }^{4}$ \\ ${ }^{1}$ National Aviation University, Department of Air Transport Economics, 1, Kosmonavta Komarova \\ ave., Kyiv, 03058 Ukraine \\ ${ }^{2}$ National Aviation University, Department of Air Transport Economics, 1, Kosmonavta Komarova \\ ave., Kyiv, 03058 Ukraine \\ ${ }^{3}$ Prima Leader Group, 3, Bohdan Khmelnytsky ave., Kyiv, 01030 Ukraine \\ ${ }^{4}$ Kyiv National University of Technology and Design, Kyiv, Ukraine
}

\begin{abstract}
The article is devoted to the development of an economic security potential management mechanism of an enterprise in a dynamic external environment. Theoretical approaches to defining its essence are investigated, their systematization is carried out and the concept of "economic security potential management mechanism of an enterprise" is suggested, based on a two-pronged approach and, based on it, it is possible to make adaptive management decisions. The characteristic features and the main purpose of the economic security potential management mechanism of an enterprise are determined, its subject and object are substantiated. The basic approaches to forming the economic security potential management mechanism of enterprises are summarized, namely: systemic, process, resource, strategic, target, synergistic, functional and complex. It is established that the economic security potential management mechanism of enterprises performs both universal functions, namely: organizational, control, motivation, planning, and specific, including protective, regulatory, preventive, information, innovative, compensatory and social. It is suggested to consider a strategic approach as a management approach, as managing economic security potential is a complex task with many variables, random factors and various constraints. Errors in managerial decisions lead to bankruptcy.
\end{abstract}

\section{Theory of the matter.}

Management of activity of enterprises and their individual types is carried out with the use of various mechanisms, based on certain resources at the appropriate stages of development and state of the environment. E.g., such authors as N. Nizhnik, G. Lelikov, S. Mosov, I.V. Zhukova works $[10,6]$ consider the organizational and economic mechanism as a set of states and processes that make up a certain economic phenomenon that causes certain movements of the system. However, it should be noted that this definition does not reveal the main components (elements) of the mechanism and their relationship. According to the considerations of works by L. Tranchenko, Yu.M. Osipova, A.A. Malitsky, T.V. Polozova, Yu. V. Ovsyuchenko [15, 8, 
12], organizational and economic mechanism is a set of organizational forms and economic levers, the interaction of which will allow to ensure the successful performance of the enterprise. In the definitions presented, the authors pay attention to the motivational methods that are included in the system of organization and management, their specific features are noted, but not specified. It should be noted that the "set of forms, methods and tools" does not always affect the change of others, not always determined by the content of the blocks and the corresponding elements that are part of the control mechanism. The more substantiated positions are followed by S.T. Piletska, O.M. Shkilnyuk, V.O. Fedorovich, A. Sokolova, A. M. Bukreeva, A.G. Goncharukin in $[11,16,14,3,5]$, which consider organizational and economic mechanism as a system of interrelated, interdependent and clearly ordered organizational and administrative actions, implemented through economic methods, controls and incentives. It should be noted that the authors consider in more detail the concept by specifying methods, controls, incentives and management methods by defining their interaction.

\section{Discussion of results}

Fluctuating economic environment, conditions of fierce competition, intensified by the global financial and political crises, led to a decline in economic activity. Many machinebuilding enterprises operating in unfavorable economic conditions are experiencing a deep decline in production or find themselves in a critical situation. In general, economic security determines the ability of an enterprise to develop, increase the competitiveness and competitiveness of its commodity products and maintain its position in competitive markets. At the same time, the economic security of the enterprise reflects its ability to protect itself against any threats that are achieved through qualitative diagnostics and use of existing and potential resources of the enterprise. Diagnosing the economic security of an enterprise, it is a comprehensive multilevel study of the external and internal environment, and the company, which gives the opportunity to develop strategic directions, on the basis of which security is provided a system development strategy, a strategic plan for its provision. [1, p. 15]. High moral depreciation and wear and tear on fixed assets, lack of financial resources, and breaking of cooperative ties put most machine-building enterprises in a difficult financial position. As a result, there is the problem of managing the potential of economic security, which is may lead to conditions for reducing the level of threats to the activity of enterprises on the basis of strategic decisions, which is one of the most important tasks of science and practice. An important element of the enterprise security system is the mechanism of its management, which ensures the achievement of security goals and tasks. In the system of economic security of the enterprise under the mechanism should be understood in a certain way the order of the sequence of states and processes that ensure the economic security of the enterprise [7, p. 123-124].

The analysis of approaches to defining the concept of "organizational and economic mechanism" and the essence of the potential of economic security suggested a mechanism to manage the potential of economic security of enterprises as a dynamic element of the management system, which is, firstly, the scientific concept of managing the potential of economic security of enterprises in the direction, which is determined by their strategy, with a view to achieving appropriate competitiveness in the internal and external markets, secondly, it is a set of practical organizational and economic instruments of influence of the management entity on the managed object for the further development through qualitative assessment of the components of economic security potential, as well as the use of objective strategic recommendations by the relevant managers (Fig. 1). 


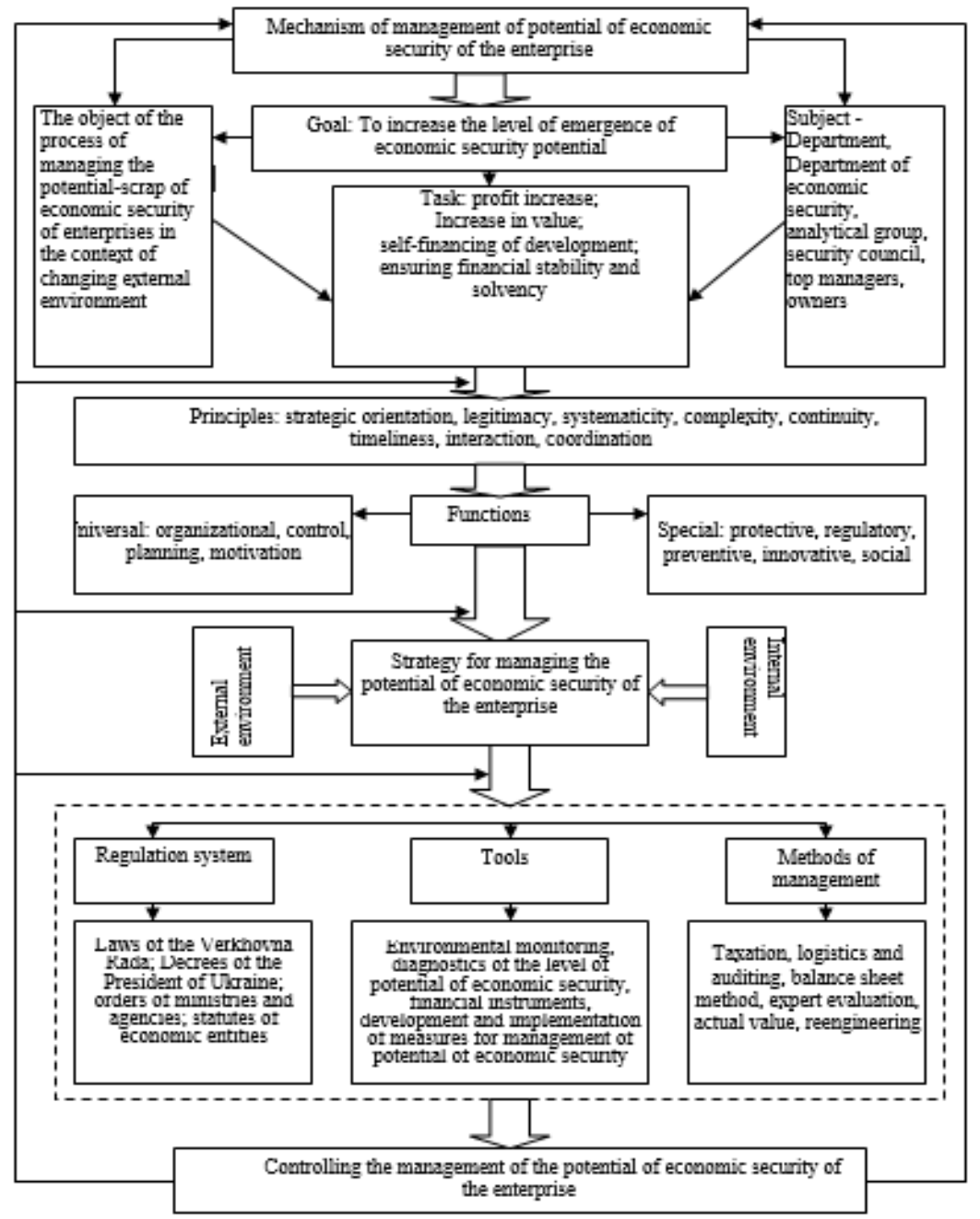

Fig. 1 Economic security potential management mechanism of the enterprise

The economic security potential management mechanism of the enterprise has the following features: dynamism and constant improvement of elements of the mechanism based on the analysis of the effectiveness of the adopted strategy; ability to change according to the external and internal environment of the enterprise functioning; effective use of economic security potential to reduce the level of threats to the enterprise; integrity and hierarchy of the structure, which allows to consider economic security as a whole and at the same time to analyze its structural subsystems and their relationship.

It should be noted that the main purpose of the economic security potential management mechanism of the enterprise is increasing the level of emergence of the potential when external environment is changing, which is achieved by maximizing the use of available resources during formulating and implementing the appropriate strategy to ensure sufficient working capital strategic measures.

The object of the mechanism is the process of managing the potential of economic security of enterprises in a changing external environment. The subject of the mechanism is a set of principles, methods, tasks, and practical aspects of managing the potential of economic security of enterprises. However, it is advisable for the entities of the mechanism to select the structural 
elements responsible for managing economic security potential: department or office of economic security, analytical group, security council, crisis expert group, specialists, top managers, owners, etc. (depending on the organizational form of the enterprise and its economic security policy).

The economic security potential management mechanism of enterprises should be based on certain principles: providing strategic orientation, which involves the use of strategic information in the analysis of the environment, identifying key problems that significantly affect the activity of the enterprise, the analysis of strategic alternatives to development, identifying the possibility of changing existing and emerging trends and etc .; orientation on the use of the potential of economic security, which helps to counteract negative changes in the external and internal environment of the enterprise; systematicity and complexity involves the use of systematic analysis and comprehensive consideration of factors in decision making. All elements of a managed system are considered in the aggregate, integrity and unity; legality involves the development of an economic security management system in accordance with national law; continuity, that is, continuous management of the potential of economic security; the need to justify the time horizon for solving strategic management problems regarding the utilization of the enterprise's potential of economic security; timeliness, namely, the development of preventive measures that will avoid or minimize the negative effects of potential threats; economic feasibility involves comparing the costs of managing economic security potential with potential losses; interaction and coordination of all business units.

The identification of the economic security potential management mechanism of enterprises should be implemented through universal and specific functions. The universal functions include organizational, control, motivation, planning [4]. The organizational function is to provide the process of managing the potential of economic security with the necessary labor, intellectual resources, means of labor, coordinating the activities of interested units and individuals. The control function is to identify trends of external and internal factors that negatively affect the process of managing the potential of economic security, and to develop suggestions for their elimination or elimination of action. The motivation function encompasses the development and use of incentives for effective interaction between the subjects of joint activity, to ensure the performance of work by members of the enterprise in accordance with the duties and plan. Planning as a function of the mechanism is to determine the guidelines for the future state of the enterprise; contributes to solving problems that arise in the process of strategy formation; makes necessary control of the execution, accounting and analysis. The economic security potential management mechanism of enterprises performs a number of important special functions, among which there protective, regulatory, preventive, information, innovative, compensatory and social. The performance of the protective function implies the prevention of internal and external threats to the enterprise and assumes that it has sufficient resource potential. In order to implement the protective function, the following conditions must be met: availability and effective utilization of the personnel and economic potential of the enterprise; optimization of available resources; development of human potential, management and human resources of the enterprise; protection of the enterprise from negative external influence, neutralization of threats and risks. Achieving a uniform motion of the enterprise (i.e. perfect interpenetration) becomes possible if the same pace and density of managerial influences are achieved. In such circumstances, the main purpose of managing dynamic changes in structural transformations is to increase the velocity per unit time in the planning period, since this will allow accelerating the main competitive processes [2, C 129-130]. The regulatory function of the economic security potential management mechanism involves regulating the state of the environment of the enterprise. The most important elements of such regulation are most often indicators that are influenced by the conditions of the external (market characteristics, competition, price level, etc.) and the internal environment of the enterprise. The preventive function of the economic security potential management mechanism of the enterprise is aimed 
at forecasting the situation and preventing the occurrence of critical situations, internal and external threats and risks. The implementation of this function is based on the development of many measures of economic, technological and organizational nature. The most important of these are measures that minimize the negative impact on the potential of economic security of the enterprise and the formation of an information security system.

The development of forecasts and preventive measures is based on the fulfillment of the information function, since the qualitative, adequate, reliable and timely information is needed for the qualitative prediction of risks, threats and the definition of effective measures. The information function is to centralize, systematize and process the incoming information, to form recommendations based on it to ensure the emergence of the potential of economic security of the enterprise. The innovative function of the economic security potential management mechanism is based on the development and further implementation of innovative solutions and measures to overcome emerging and already existing threats. The purpose of the compensation function is threefold: to eliminate the threat - to eliminate the consequences - to compensate for the loss. The social function of the economic security potential management mechanism is trying to achieve the highest level and quality of life of the owner and employees of the enterprise, through mutual partnership. The effectiveness of the financial security system of the enterprise depends on the mechanisms of its provision. A financial security mechanism is a set of tools, such as methods, resources, regulatory framework and managerial incentives, which, while interacting with each other, are intended to achieve the goals set to address the issue of ensuring the financial security of the enterprise. Formation of the economic security potential management mechanism of enterprises occurs through the implementation of certain actions on its objects, including profit, sources and volumes of financial resources, capital structure, structure of cash flows, structure of assets, investments, financial risks, system of financial innovations, etc. [17].

Elements of the economic security potential management mechanism are methods, tools, rules and regulations (regulatory system), information and analytical support system. The methods of the economic security potential management mechanism are the set of techniques and operations by which the enterprise manages the potential of economic security through the use of the following methods: technical and economic calculations, tax optimization, logistics and audit methods, balance sheet method, asset depreciation, economic and statistical method, expert assessments, present value, re-engineering, etc. In order to organize the process of managing the economic security potential, it is advisable to use the following tools: environmental monitoring, diagnostics of the level of economic security potential of the enterprise, financial instruments (payment, credit, deposit, etc.), development and implementation of measures to manage the potential of economic security. The system of regulation includes: Laws of the VerkhovnaRada; Decrees of the President of Ukraine; orders of ministries and departments; statutes of economic entities. Information support - economic, commercial, financial and other information - can be used as business reports, Internet; media and others.

Thus, the organizational and economic mechanism of economic security potential management of the enterprise involves the achievement of effective parameters of functioning, preservation of financial, production and personnel potential, formation of conditions for reliable and competitive functioning. The suggested structure of the organizational and economic mechanism for managing the potential of economic security of the enterprise reflects the economic and organizational components where a special place belongs to controlling.

\section{Conclusion}


The main purpose of the economic security potential management mechanism is to ensure the effective functioning, productive operation of the operating system and the economic use of resources, to ensure a certain level of labor potential of the personnel and the quality of economic processes of the enterprise, as well as constant stimulation for increasing the existing potential and its stable development. The general concept of operation of the suggested economic security potential management mechanism of the enterprise involves the creation of a system that provides recognition of threats, forecasting their consequences, determining methods of localization and submission of information to the general management system, where operational decisions to eliminate threats, or adjust the strategic goals of the enterprise. The implementation of the suggested mechanism requires the creation of an economic security monitoring system that allows providing adequate information support of the activity of the mechanism taking into account not only the external, but also the internal environment.

\section{References}

1. Arefieva Olena V., Miahkykh Iryna M., Shkoda Mariana S. Bulletin of the Kyiv National University of Technologies and Design. Series: Economic sciences, 3, 8-17 (2019)

2. Arefiev S. O. Economic Bulletin of the National Mining University, 1, 124-132 (2016)

3. Bukreev A. M. Organizatsionno-ekonomicheskiy mekhanizm antikrizisnogo upravleniya: teoriya i praktika.Voronezh (in Russian) (2000)

4. Herchikova I. N. Menedzhment: uchebnik. M.: UNITY. (in Russian) (1997)

5. Honcharuk A. H. Formuvannia mekhanizmu upravlinnia efektyvnistiu pidpryiemstva (na prykladi kharchovoi promyslovosti). (PhD Thesis), Odessa: Inst. market and eco-ecologist. research. NAS of Ukraine (2010)

6. Zhukova I.V. Power and management in the east of Russia, 4, 43-49 (2010)

7. Ladyko L. N. Scientific Bulletin of Poltava University of Economics and Trade. Series: Economic Sciences, 3, 123-126 (2014)

8. Malytskyi A. A. Proceedings of the XIV International Scientific Internet Conference ADVANCED TECHNOLOGIES OF SCIENCE AND EDUCATION (Ukraine, Kyiv, December 20-28, 2018). Available at: http://intkonf.org/malitskiy- aa-organizatsiynoekonomichniy-mehanizm-upravlinnya-pidpriemstvom-sutnist-ta-struktura

9. Mykhailenko V. M., Arefiev S. O. Formuvannia orhanizatsiinoho potentsialu rozvytku ekonomichnoi bezpeky pidpryiemstv: monohrafiia. Lviv: Ukr. Acad. Printing. (in Ukrainian) (2010)

10. Nyzhnyk N., Lelikov H., Mosov S. Bulletin of the Civil Service of Ukraine, 3, 80-87 (2001)

11. Piletska S. T. Antykryzove upravlinnia ekonomichnoiu stiikistiu promyslovoho aviapidpryiemstva. K.: Center for Educational Literature. (in Ukrainian) (2014)

12. Polozova T. V., Ovsiuchenko Iu. V. Vesntnik VSU, 1, 63-65 (2005)

13. Prokhorova V.V., Yatsenko B. I. Business Inform, 11, 386-391 (2016)

14. Sokolova A. O. KNETE Bulletin, 2, 88-92 (2006)

15. Tranchenko L. V., Balastryk L. O. Problemy udoskonalennia orhanizatsiinoekonomichnoho mekhanizmu upravlinnia pidpryiemstvom. K.: Kiev University, vol. 7, pp. 188-195 (2005)

16. Shkilniuk O. M. Orhanizatsiino-ekonomichnyi mekhanizm rehuliuvannia innovatsiinoi diialnosti (PhD Thesis), K .: Economic Research Institute (2008)

17. Shtanhret A.M., Kotliarevskyi Ya.V., Karaim M.M. Ekonomichna bezpeka pidpryiemstva $v$ umovakh antykryzovoho upravlinnia: kontseptualne vyznachennia ta mekhanizm zabezpechennia: monohrafiia. Lviv: Ukr. Acad. Printing. (in Ukrainian) (2012) 